\title{
Peranan Etika Kerja Islam terhadap Hubungan Locus of Control dengan Kinerja Karyawan
}

\author{
Ridwan \\ Fakultas Ekonomi, Universitas Tadulako \\ Kampus Bumi Bahari Tadulako, Tondo, Palu, Sulawesi Tengah \\ E-Mail: ridwanuntad@yahoo.co.id
}

\begin{abstract}
This study's objectives to asses moderating effect of Islamic work ethic variable to relationship in between locus of control with employers performance. The asses used Simple linear regression and Moderating Regression Analysis (MRA). Census method was used this study which included 32 responden from PT Bank Muamalat Indonesia Tbk. Cabang Palu employers. Result of the study indicated significantly effect of Islamic work ethic from relationship between locus of control to employers performance. Interaction coeficient marked negatif with significant $\rho$ about $0.014(\rho<0.05)$ that it mind variable of islamic work ethic would be moderating variable which its fungtion diluted relationship locus of control to employers performance. Therefore, it need carefully to handle Islamic work ethic of employers if want to improve their performance by locus of control percieved.
\end{abstract}

Keywords: moderating effect, simple linier regression, moderating regression analysis.

\begin{abstract}
ABSTRAK
Studi ini bertujuan untuk menguji pengaruh variabel memoderasi etika kerja Islam terhadap hubungan locus of control dengan kinerja karyawan. Pengujian ini dilakukan dengan menggunakan Simple linear regression dan Moderating Regression Analysis (MRA). Penelitian yang menggunakan metode sensus ini melibatkan sebanyak 32 karyawan PT Bank Muamalat Indonesia Tbk. Cabang Palu sebagai responden. Hasilnya menunjukkan pengaruh etika kerja Islam secara negatif terhadap hubungan antara locus of control dan kinerja karyawan. Koefisien interaksi bertanda negatif dengan signifikansi $\rho$ sebesar $0.014(\rho<0.05)$ memberi arti bahwa variabel etika kerja Islam merupakan variabel moderating yang mana etika kerja Islam memperlemah hubungan antara locus of control dengan kinerja karyawan. Dengan demikian, perlu penanganan yang hati-hati tentang etika kerja Islam pada karyawan sehubungan dengan persepsian locus of control untuk meningkatkan kinerjanya.
\end{abstract}

Kata Kunci: etika kerja Islam, locus of control, kinerja karyawan. 


\section{LATAR BELAKANG}

Setiap individu berpengaruh langsung sebagai efek substantif dalam pandangan dan reaksinya terhadap lingkungan (Spector, 1986 dalam Karimi dan Alipour, 2011). Efek substantif ini, menurut Rotter (1966) yang dikutip Engko dan Gudono (2007) disebut locus of control atau adanya keyakinan seseorang terhadap sumber yang mengontrol kejadian-kejadian dalam hidupnya. Locus of control berhubungan baik dengan beberapa variabel seperti stress, etika kerja, kepuasan kerja, dan kinerja. Falikhatun (2003:264) mengemukakan bahwa peningkatan kinerja pegawai dalam pekerjaan pada dasarnya akan dipengaruhi oleh kondisi-kondisi tertentu, yaitu kondisi yang berasal dari luar individu yang disebut dengan faktor situasional dan kondisi yang berasal dari dalam yang disebut dengan faktor individual.

Faktor situasional meliputi kepemimpinan, prestasi kerja, hubungan sosial, dan budaya organisasi. Khusus pada prestasi kerja akan dipengaruhi oleh faktor eksternal, seperti keberuntungan, nasib, kekuasaan atasan, dan lingkungan sekitar. Sementara, faktor internal merupakan keyakinan bahwa keberhasilan dapat diperoleh dari hasil kerja keras. Dengan demikian, karyawan yang memiliki locus of control faktor internal akan memiliki kinerja yang lebih baik. Karyawan yang bekerja keras dengan mematuhi etika kerja secara profesional, tentunya akan memperoleh hasil kinerja yang lebih baik.

Menurut Menezes (2008) individu yang beretika baik memiliki locus of control internal lebih tinggi dibanding dengan locus of control eksternal. Dengan demikian, personality pada faktor internal terutama locus of control pada gilirannya menjadi faktor penting untuk menentukan perilaku di dalam organisasi maupun sikap kerja karyawan. Selanjutnya Ghozali (2002) mengemukakan bahwa hubungan antara tingkat religiusitas dan sikap karyawan dapat dijelaskan dari sudut pandang teori personality yang dinyatakan bahwa tingkat religiusitas akan menjadi bagian dari identitas diri seseorang (personality). Oleh karena itu, perlu dikaji peranan personality religiusitas terhadap locus of control dalam peningkatan kinerja karyawan. Personality religiusitas yang dikaji dalam hal ini adalah etika kerja karyawan muslim yang mayoritas di Indonesia, yaitu $85 \%$ (BPS, 2010).

\section{Etika Kerja Islam}

Istilah etika sering dibandingkan dengan moralitas, etika dan moralitas sering dipertukarkan atau diberikan pengertian yang sama, hal tersebut tidak sepenuhnya salah, hanya saja perlu diperhatikan bahwa etika bisa memiliki pengertian yang sangat berbeda dengan moralitas (Sundary, 2010). Dengan demikian, etika merupakan penjabaran rasional yang terkandung dalam aturan praktis untuk menunjukkan sesuatu yang baik dan benar.

Dewi dan Bawono (2008) menjelaskan bahwa ada beberapa sistem etika yang sering digunakan, yaitu utilitarianisme yang digunakan untuk merumuskan konsep dan melakukan kajian. Deontologisme digunakan dalam penetapan kode etik professional. Sistem-sistem etika tersebut, terdapat pula etika alternatif yang diajukan berdasarkan pada nilainilai transedental iman dan pengetahuan, yang lebih dikenal dengan syaria'ah sebagai landasan etika kerja Islam. Dewi dan Bawono (2008), membedakan etika syari'ah (etika kerja islam) dengan sistem etika lainnya, yaitu berkaitan dengan niat, cara meraih tujuan serta sumber penentuan nilai.

Etika kerja Islam patut untuk mendapatkan perhatian karena merupakan hal yang ideal dimana seorang muslim berusaha untuk mewujudkannya (Yousef, 2000). Konsep etika Islam memiliki karakter atau ciri khusus yaitu mengatur tentang bagaimana hubungan manusia dengan Tuhan, dengan sesama manusia, dengan lingkungan, dan masyarakat. Etika Islam bersumber pada firman Allah SWT yang autentik, yaitu Alquran dan Hadist yang merupakan contoh-contoh dari kehidupan nabi Muhammad SAW, serta Ijma dan Qiyas. Hukum dan ketetapan etika dapat dijadikan pegangan dan pedoman hidup, yaitu berlandaskan pada dasar-dasar moral yang ditetapkan oleh Allah SWT.

Anik dan Arifudin (2003) mengemukakan bahwa etika terekspresikan dalam bentuk syariah terdiri dari Alquran, Sunnah Hadits, Ijma, dan Qiyas. Etika syari'ah mempunyai sifat humanistik dan rasionalsitik. Sifat rasionalistik bahwa semua pesan-pesan yang diajarkan Alquran sejalan dengan prestasi manusia yang tertuang dalam karya-karya para filosof. Ajaran yang terdapat dalam Alquran seperti ajaran kepada kebenaran, keadilan, kejujuran, kebersihan, menghormati orang tua, bekerja keras, dan cinta ilmu semuanya tidak ada yang berlawanan 
dengan kedua sifat tersebut. Sejalan dengan hal tersebut, Mahiyaddin (2009) merinci bahwa etika kerja Islam mengutamakan nilai-nilai murni, seperti kehormatan manusia, mementingkan ketaatan, dan ketekunan kerja.

Menurut Sundary (2010), ajaran Islam yang bersumber dari Alquran dan Hadits sebagai pedoman yang bersifat universal, menggariskan norma-norma etika dalam bekerja dan berusaha sebagai berikut:

a. Niat yang baik, karena niat sangat menentukan terhadap nilai suatu kerja, maka niat harus betulbetul tulus dan ikhlas. Maksudnya niat bekerja harus didasarkan "karena Allah". Bila niat ditujukan karena Allah, maka akan memiliki dimensi ibadah, yang tentunya akan mendapat imbalan pahala dari Allah SWT, di samping imbalan materi sebagai hasil kerjanya. Dalam kaitan dengan niat yang baik ini ada sabdah Rasulullah SAW: "Sesungguhnya seluruh amal (pekerjaan) itu tergantung pada niatnya" (H.R Bukhari-Muslim), maksudnya niat itu adalah kunci dalam bekerja dan berusaha.

b. Tidak melalaikan kewajibannya kepada Allah SWT. Sebagai makhluk Tuhan yang diberikan kesempurnaan ciptaan, manusia mempunyai seperangkat kewajiban kepada Allah SWT dalam bentuk Ibadah, sehingga setiap pekerjaan yang dilakukan manusia tidak sampai melalaikan ibadah kepadaAllah. Hal ini sejalan dengan seruan Allah dalam Alquran: "Hai orang-orang yang beriman, apabila kamu diseru untuk menunaikan salat pada hari Jum'at, maka bersegeralah kamu mengingat Allah dan tinggalkanlah jual beli. Yang demikian itu lebih baik bagimu jika kamu mengetahui” (Q.S. Al Jumu'ah: 9).

Ayat tersebut menegaskan betapa pentingnya pelaksanaan salat dibanding aktivitas usaha. Bila adzan berkumandang maka aktivitas jual beli dan pekerjaan lainnya harus dihentikan untuk sementara. Hal ini berarti bahwa dalam bekerja, selalu mengindahkan norma-norma yang telah digariskan Allah SWT, batas mana yang boleh dan mana yang tidak boleh dikerjakan.

c. Suka sama suka antara pihak-pihak yang bersangkutan. Etika ini didasarkan pada firman Allah dalam Alquran, Surat An-Nisa (4:29) yang berbunyi: "Hai orang-orang yang beriman, janganlah kamu saling memakan harta bersamamu dengan jalan yang bathil, kecuali dengan jalan perdagangan yang berlaku dengan suka sama suka. Dan janganlah kamu membunuh dirimu, sesungguhnya Allah Maha Penyayang padamu."

Etika suka sama suka ini merupakan satu isyarat bahwa betapa pentingnya hubungan yang harmonis antara pedagang dengan pembeli, antara produsen dengan konsumen, antara buruh dengan majikan, dan antara bawahan dengan atasan karena kedua belah pihak itu saling membutuhkan (interdependensi). Dalam etika suka sama suka juga tersirat adanya pengakuan terhadap hak asasi manusia dalam arti yang luas. Secara sederhana, hak-hak pekerja harus mendapat perlindungan, kompetisi dalam setiap kehidupan dan profesi memang diakui dalam Islam, tetapi harus dengan cara yang sehat (fair), yang intinya tidak mengorbankan hak dan kepentingan orang lain.

d. Dilandasi akhlak dan mental yang baik. Setiap aktivitas atau pekerjaan yang islami harus dilandasi oleh akhlak yang mulia, karena itu para pekerja atau pegawai, pedagang ataupun pekerjaan lainnya harus mempunyai akhlak dan sikap mental yang baik. Hal ini dapat dianalogikan dari sabda Rasulullah SAW: "Pedagang yang jujur, benar lagi muslim, kelak di hari kiamat akan bersama-sama para syuhada".

Salah satu ayat dalam Alquran yang menekankan pentingnya bekerja, adalah. "Seorang tidak mendapatkan sesuatu, kecuali apa yang telah diusahakannya" (Q.S. An-Najm: 39).

Ayat ini dengan nyata menjelaskan bahwa satu-satunya cara untuk menghasilkan sesuatu dari alam adalah dengan bekerja keras. Keberhasilan dan kemajuan manusia di muka bumi ini tergantung pada usahanya. Semakin keras ia bekerja, ia akan semakin kaya. Prinsip ini lebih lanjut dijelaskan dalam ayat-ayat berikut: "Bagi seorang laki-laki ada manfaat dari apa yang dia usahakan. Dan bagi wanita ada bagian yang mereka usahakan" (Q.S. An-Nisa: 32).

Alam tidak mengenal pemisahan manusia, antara laki-laki dan perempuan, antara yang hitam dan putih, bahkan antara muslim dan non muslim, masing-masing dari mereka diberi balasan atas apa yang dikerjakannya. 
Mahiyaddin (2009) menjelaskan bahwa orientasi etika kerja Islam yang utama adalah kerja. Etika kerja Islam memandang individu yang bekerja keras untuk mencari nikmat, rejeki dalam keridhaan Yang Maha Kuasa merupakan satu sifat dasar dan diyakini akan mencapai kesuksesan dalam hidupnya, sedangkan yang tidak melakukan kerja keras akan menemui kegagalan dalam hidupnya. Barang siapa bekerja keras ia akan mendapat balasannya. Prinsip ini berlaku untuk setiap individu dan juga untuk semua bangsa. "Allah sekali-kali tidak akan mengubah nasib suatu bangsa, sehingga bangsa itu mengubahnya sendiri" (Q.S. Al-Anfal: 53).

Fitria (2003) menjelaskan bahwa terdapat beberapa faktor-faktor penting tentang penghayatan etika kerja Islam yang harus diperhatikan, yaitu adanya keterikatan individu terhadap diri dan kerja yang menjadi tanggung jawabnya; berusaha dengan cara halal dalam seluruh jenis pekerjaan dengan pengembangan pribadi dan hubungan sosial; dilarang memaksakan (memforsir) seseorang, alat-alat produksi atau binatang dalam kerja; tidak mengenal pekerjaan yang mendurhakai Allah SWT seperti di antaranya bekerja memeras bahan-bahan minuman keras dan sebagai pencatat riba; di antara sifat pekerja adalah kuat dan dapat dipercaya; dan profesionalisme.

\section{Locus Of Control}

Konsep locus of control pertama kali dikemukakan oleh Jullian Rotter pada Tahun 1966 yang mana teori ini merupakan perkembangan dari teori belajar sosial (Jaya dan Rahmat, 2005). Ayudiati (2010) menjelaskan bahwa locus of control merupakan cara pandang seseorang terhadap suatu peristiwa apakah dia merasa dapat atau tidak mengendalikan perilaku yang terjadi padanya. Ditambahkan pula oleh Jaya dan Rahmat (2005) bahwa locus of control adalah suatu cara yang mana individu memiliki tanggung jawab terhadap kegiatan yang terjadi di dalam kontrol atau di luar kontrol dirinya. Engko dan Gudono (2007) mendefinisikan locus of control sebagai cara pandang seseorang apakah ia dapat mengendalikan peristiwa yang terjadi padanya. Dengan demikian, locus of control merupakan keyakinan seseorang terhadap kemampuannya untuk mengendalikan diri.

Ida dan Dwinta (2010) membedakan orientasi locus of control menjadi dua, yakni locus of control internal dan locus of control eksternal, hal ini dijelaskan bahwa individu dengan locus of control internal cenderung menganggap bahwa keterampilan (skill), kemampuan (ability), dan usaha (effort) lebih menentukan apa yang mereka peroleh dalam hidup. Individu dengan locus of control eksternal cenderung menganggap hidup mereka lebih ditentukan oleh kekuatan dari luar diri mereka, seperti nasib, takdir, dan keberuntungan.

Menurut Engko dan Gudono (2007), locus of control internal akan tampak melalui kemampuan kerja dan tindakan kerja yang berhubungan dengan keberhasilan dan kegagalan karyawan pada saat melakukan pekerjaannya, sedangkan locus of control eksternal bagi seseorang terlihat pada saat melakukan pekerjaan, maka keberhasilan pekerjaan yang dilakukan akan sangat dipengaruhi oleh faktor dari luar dirinya. Sementara, Menezes (2008) menjelaskan bahwa Locus of control internal mengacu pada persepsi individu terhadap kejadian, baik kejadian positif maupun negatif sebagai konsekuensi dari tindakan atau perbuatan diri sendiri dan berada di bawah pengendalian dirinya. Locus of control eksternal mengacu pada keyakinan bahwa suatu kejadian tidak memiliki hubungan langsung dengan tindakan yang dilakukan oleh diri sendiri dan berada diluar kontrol dirinya.

Individu dengan locus of control internal memiliki keyakinan bahwa mereka mampu mengendalikan dan mengelola kehidupan mereka sendiri dengan membuat keputusan atas apa yang mereka lakukan dan mereka hasilkan (Karimi dan Alipour, 2011). Lebih lanjut dijelaskan bahwa individu dengan locus of internal yang tinggi menerima bahwa prestasi dan kegagalan mereka tergantung pada usaha mereka sendiri, singkatnya mereka memiliki kemampuan untuk menentukan nasib (hasil) mereka sendiri dan mereka bertanggung jawab atas apa yang terjadi atau hasil yang diperoleh.

Karimi dan Alipour (2011) mengungkapkan bahwa orang dengan locus of control eksternal percaya bahwa unsur-unsur eksternal (faktor luar) seperti keberuntungan, kesempatan, dan takdir menentukan kehidupan mereka, serta kegagalan dan keberhasilan mereka bukan karena usaha mereka sendiri. Seseorang dengan locus of control internal yang lebih tinggi dibanding locus of control eksternalnya, memiliki rasa kepercayaan diri yang tinggi dalam menjalani pekerjaan dan hidup. Locus 
of control internal sangat mempengaruhi seseorang dalam bertindak dan mengambil keputusan dalam pekerjaannya dan siap dengan segala kemungikan yang akan terjadi sebagai hasil dari pekerjaan dan keputusan yang diambilnya. Namun perlu diketahui bahwa setiap orang memiliki locus of control tertentu yang berada diantara kedua ektrim tersebut. Secara teori dan yang terjadi dilapangan locus of control memungkinkan perilaku karyawan apabila dalam situasi konflik akan dipengaruhi oleh karakteristik internal locus of control-nya.

Perbedaan karakteristik antara locus of control internal dan eksternal (Ngatemin, 2009), adalah sebagai berikut:

1. Locus of control internal

a. Suka bekerja keras.

b. Memiliki inisiatif yang tinggi.

c. Selalu berusaha untuk menemukan pemecahan masalah.

d. Selalu mencoba untuk berfikir seefektif mungkin.

e. Selalu mempunyai persepsi bahwa usaha harus dilakukan jika ingin berhasil.

2. Locus of control eksternal

a. Kurang memiliki inisiatif.

b. Mudah menyerah, kurang suka berusaha karena mereka percaya bahwa faktor luar yang mengontrol.

c. Kurang mencari informasi.

d. Mempunyai harapan bahwa ada sedikit korelasi antara usaha dan kesuksesan.

e. Lebih mudah dipengaruhi dan tergantung pada petunjuk orang lain.

Bello dalam Purnomo dan Lestari ( 2010) mengemukakan variabel-variabel yang terkait dengan locus of control antara lain kinera organisasi, kepuasan kerja, stres terhadap kerja, intensi untuk berhenti kerja, kepemimpinan, entepreneurship, dan keterlibatan kerja

\section{Kinerja Karyawan}

Kinerja atau perfomance, adalah hasil kerja yang dicapai seseorang atau sekelompok orang sebagai tolak ukur dalam melaksanakan seluruh tugas yang ditargetkan atau ditetapkan. Sedarmayanti (2004) mengemukakan kinerja sebagai hasil kerja seseorang atau sekelompok orang dalam suatu organisasi dengan wewenang dan tanggung jawab masing-masing dalam upaya mencapai tujuan organisasi secara ilegal, tidak melanggar hukum dan sesuai dengan moral dan etika. Rusdy dan Septiani (2008) juga mengungkapkan kinerja pada dasarnya adalah apa yang dilakukan atau tidak dilakukan karyawan, lebih lanjut dijelaskan kinerja karyawan adalah yang mempengaruhi seberapa banyak mereka memberi kontribusi kepada organisasi, perbaikan kinerja baik untuk individu maupun kelompok menjadi pusat perhatian dalam upaya meningkatkan kinerja organisasi.

Dessler (2006) menjelaskan bahwa kinerja merupakan prestasi kerja, yakni perbandingan antara hasil kerja yang secara nyata dengan standar yang ditetapkan, dengan demikian kinerja menfokuskan pada hasil kerjanya. Kinerja (performance) sangat dipengaruhi oleh tingkat pendidikan, pengalaman kerja, dan motivasi. Kata kunci dari pengertian kinerja adalah hasil kerja pekerja (karyawan), proses atau organisasi, terbuka secara konkrit dan dapat diukur, dan dapat dibandingkan dengan standar yang telah ditentukan (Sedarmayanti, 2004).

Ribhan (2008) mengemukakan ada tiga variabel yang mempengaruhi perilaku dan prestasi kerja karyawan, yaitu variabel individual, variabel organisasional, dan variabel psikologis.

Menurut Dessler (2006) bahwa ada lima faktor dalam penilaian kinerja yang popular, yaitu:

1. Prestasi pekerjaan, meliputi: akurasi, ketelitian, keterampilan dan penerimaan pengeluaran.

2. Kuantitas pekerjaan, meliputi: volume keluaran dan kontribusi.

3. Kepemimpinan yang diperlukan, meliputi: membutuhkan saran, arahan atau perbaikan.

4. Kedisplinan, meliputi: kehadiran, sanksi, regulasi, dapat dipercaya atau diandalkan, dan tepat waktu.

5. Komunikasi, meliputi: hubungan antar karyawan maupun dengan pimpinan, media komunikasi.

\section{METODE}

Penelitian ini dilakukan dengan menyebarkan angket kuesioner ke responden. Responden 32 karyawan PT Bank Muamalat Indonesia Tbk. Cabang Palu. Kuesioner diserahkan ke responden secara langsung di kantor PT Bank Muamalat Indonesia Tbk. Cabang Palu.

Adapun operasional variabel pada penelitan ini menggunakan instrumen yang telah digunakan pada penelitian sebelumnya, dapat dilihat pada Tabel 1. 
Tabel 1. Tabel Matriks Operasional Variabel

\begin{tabular}{llll}
\hline \multicolumn{1}{c}{ Variabel } & \multicolumn{1}{c}{ Sub Variabel } & \multicolumn{1}{c}{ Indikator } & Skala \\
\hline Locus of Control & 1. Locus of Control Eksternal & a. Nasib & Ordinal \\
(Ida dan Dwinta, 2010) & b. Takdir & Ordinal \\
& c. Keberuntungan & \\
Etika Kerja Islam & a. Kemampuan & \\
(Yousef, 2000) & b. Usaha & c. Keterampilan \\
& a. Kuat dan dapat dipercaya & Ordinal \\
Kinerja karyawan & b. Profesionalisme & c. Filosofi bekerja \\
(Ayudiati, 2010) & d. Pengembangan pribadi dan hubungan sosial \\
& e. Pengendalian alam semesta & a. Kuantitas Kerja Karyawan \\
\hline
\end{tabular}

Sumber: data diolah, 2012

Instrumen penelitian yang digunakan dalam penelitian ini diukur dengan menggunakan skala sikap yang dikelompokkan dalam lima bagian dari 1 sampai 5. Perubahan skala ordinal ke interval menggunakan Method of Successive Interval (MSI) dengan bantuan MS. Office Excell 2010. Instrumen pengukuran dan pengujian hipotesis dilakukan menggunakan bantuan program SPSS For Windows 16. Pengujian hipotesis dilakukan dengan menggunakan persamaan regresi sederhana dan Moderating Regression Analysis (MRA).

\section{Locus of Control terhadap Kinerja Karyawan}

Orang-orang yang memiliki locus of control internal faktor kemampuan dan usaha terlihat dominan, oleh karena itu apabila dengan locus of control internal mengalami kegagalan akan menyalahkan dirinya sendiri karena kurangnya usaha yang dilakukan, begitu pula dengan keberhasilan, mereka akan merasa bangga atas hasil usahanya. Orang yang memiliki locus of control eksternal melihat keberhasilan dan kegagalan dari faktor kesukaran dan nasib, oleh karena itu apabila mengalami kegagalan mereka cenderung menyalahkan lingkungan sekitar yang menjadi penyebabnya, hal ini tentunya berpengaruh terhadap tindakan dimasa datang, karena merasa tidak mampu dan kurang usahanya maka mereka tidak mempunyai harapan untuk memperbaiki kegagalan tersebut.
Locus of Control dalam pemahaman Karimi dan Alipour (2011) mengarah pada kemampuan seseorang individu dalam mempengaruhi kejadian yang berhubungan dengan hidupnya. Locus of control adalah cara pandang seseorang terhadap suatu peristiwa apakah dia dapat atau tidak mengendalikan peristiwa yang terjadi padanya (Rotter dalam Prasetyo, 2002). Berdasarkan teori locus of control memungkinkan bahwa perilaku karyawan dalam situasi konflik akan dipengaruhi oleh karakteristik internal Locus of control-nya dimana locus of control internal adalah cara pandang bahwa segala hasil yang didapat baik atau buruk adalah karena tindakan kapasitas dan faktor-faktor dalam diri mereka sendiri. Ciri pembawaan internal locus of Control adalah mereka yang yakin bahwa suatu kejadian selalu berada dalam rentang kendalinya dan kemungkinan akan mengambil keputusan yang lebih etis dan independen. Locus of control berperan dalam motivasi, locus of control yang berbeda biasanya mencerminkan motivasi yang berbeda dan kinerja yang berbeda. Dalam teori X dan Y yang ditemukan oleh McGregor dalam Maya Febrianty Launita (2011) menyatakan bahwa individu yang memiliki locus of control eksternal akan bertipe X dikarenakan mereka tidak menyukai tanggung jawab, dan harus dipaksa agar berprestasi, mereka harus dimotivasi oleh lingkungannya, sedangkan untuk locus of control 
internal akan bertipe Y dikarenakan mereka meyukai kerja, kreatif, berusaha bertanggungjawab, dan dapat menjalankan pengarahan diri.

Beberapa penelitian terdahulu tentang locus of control dan kinerja, misalnya Menezez (2008) menunjukkan internal auditor yang ber-locus of control internal memiliki kinerja yang lebih tinggi dari internal auditor yang memiliki locus of control eksternal. Selanjutnya, Rusdy dan Septiani (2008) membuktikan bahwa ada pengaruh positif dan signifikan antara stres kerja yang terdiri atas konflik kerja dan beban kerja terhadap kinerja karyawan pada. Penelitian Reny Mustikawati (1999) menyimpulkan bahwa locus of control tidak berpengaruh terhadap anggaran partisipatif. Penelitian Gendut Sukarno (2003) menyimpukan adanya hubungan antara stres kerja yang ber-locus of control eksternal dengan kinerja karyawan. Penelitian Noer dan Ikhsan (2007) menunjukan locus of control dan kebijakan sektor publik mempunyai pengaruh terhadap kinerja aparat. Oleh karena itu, dapat disimpulkan kinerja juga dipengaruhi oleh tipe personalitas individu-individu khususnya locus of control yang digunakannya dalam menjalankan tugas kepadanya sehingga akan meningkatkan kinerja mereka. Dengan demikian, dapat dihipotesiskan, sebagai berikut:

$\mathrm{H1}$ : locus of control berpengaruh signifikan secara positif terhadap kinerja karyawan.

\section{Memoderating Etika Kerja Islam}

Temuan Ghozali (2002) memperlihatkan tingkat religiusitas dan sikap karyawan dapat dijelaskan dari sudut pandang teori personality, bahwa tingkat religiusitas akan menjadi bagian dari identitas diri seseorang (personality). Personality itu sendiri terutama locus of control pada gilirannya menjadi faktor penting untuk menentukan perilaku di dalam organisasi maupun sikap kerja karyawan. Etika kerja Islam berdasarkan Alquran dan Hadist yang menekankan untuk menjalin kerjasama dan selalu bekerja keras yang merupakan salah satu cara untuk menghapus dosa dan mencari keridhaan-Nya. Etika kerja Islam lebih berorientasi pada penyelamatan individu di dunia dan di akhirat. Adanya keyakinan bahwa Tuhan tidak akan menguji hamba-Nya melebihi kemampuannya dan percaya bahwa Tuhan akan memberikan sesuatu yang lebih indah jika kita berhasil melampauinya. Etika kerja Islam disini sebagai variabel mediating yang dapat memperkuat atau memperlemah kinerja.

Keyakinan tersebut menimbulkan adanya penghayatan, bahwa orang-orang yang mendapat tekanan atau gangguan-gangguan tidak menyenangkan, yang berasal dari luar diri seseorang merupakan tantangan bagi dirinya untuk bisa lebih maju yang terlihat dari peningkatan kinerjanya. Perusahaan atau badan usaha yang karyawannya mayoritas muslim atau $100 \%$ muslim, dengan penghayatan yang mendalam terhadap etika kerja berdasarkan tuntutan Alquran dan Hadist, diharapkan memiliki locus of control atau pengendalian diri yang baik dalam menghadapi tekanan dan gangguan-gangguan terhadap dirinya.

Orang-orang yang memiliki tingkat penghayatan religiusitas yang tinggi terutama dalam sikap etika kerjanya apabila mendapat tekanan atau gangguangangguan yang tidak menyenangkan yang berasal dari luar diri seseorang tidak akan begitu mudah berpengaruh pada faktor locus of control dan menjadikan tantangan bagi dirinya untuk bisa menjadikan dirinya lebih maju itu terlihat dari peningkatan kinerjanya. Hal ini diperkuat oleh temuan Ayudianti (2010) bahwa peranan etika kerja islam sebagai variabel moderating. Hasil penelitian ini menunjukkan bahwa analisis regresi dan uji $\mathrm{t}$ dapat diketahui bahwa variabel locus of control dan variabel etika kerja Islam berpengaruh positif terhadap variabel kinerja karyawan. Dengan demikian, dapat dihipotesiskan bahwa:

H2: Etika Kerja Islam memoderating hubungan locus of control terhadap kinerja karyawan secara signifikan positif.

\section{HASIL}

\section{Hasil Pengujian Instrumen Penelitian}

Validitas instrumen diukur dengan membandingkan nilai Corrected item - Total Correlation dari jumlah pernyataan yang diajukan dengan nilai r-kritis sesuai kriteria yaitu sebesar 0,3 . Berdasarkan hasil pengujian validitas terhadap kuesioner yang digunakan dalam penelitian ini maka dapat diketahui nilai kesahihan dari 10 item pernyataan yang mewakili variabel independen (locus of control dan etika kerja Islam) dan 9 item pertanyaan yang mewakili variabel dependen (kinerja karyawan), adalah valid. Pemaparan hasil pengujian instrumen tersebut dapat dilihat pada Tabel 2. 
Tabel 2. Hasil Pengujian Validitas

\begin{tabular}{|c|c|c|c|}
\hline Item Pertanyaan & r- hitung & r-kritis & Status \\
\hline \multicolumn{4}{|l|}{ Locus Of Control $\left(\mathrm{X}_{1}\right)$} \\
\hline 1 & 0.363 & 0.3 & Valid \\
\hline 2 & 0.376 & 0.3 & Valid \\
\hline 3 & 0.399 & 0.3 & Valid \\
\hline 4 & 0.463 & 0.3 & Valid \\
\hline 5 & 0.569 & 0.3 & Valid \\
\hline \multicolumn{4}{|l|}{ Etika Karja Islam $\left(\mathrm{X}_{2}\right)$} \\
\hline 1 & 0.350 & 0.3 & Valid \\
\hline 2 & 0.405 & 0.3 & Valid \\
\hline 3 & 0.434 & 0.3 & Valid \\
\hline 4 & 0.448 & 0.3 & Valid \\
\hline 5 & 0.415 & 0.3 & Valid \\
\hline \multicolumn{4}{|l|}{ Kinerja Karyawan (Y) } \\
\hline 1 & 0.411 & 0.3 & Valid \\
\hline 2 & 0.530 & 0.3 & Valid \\
\hline 3 & 0.497 & 0.3 & Valid \\
\hline 4 & 0.559 & 0.3 & Valid \\
\hline 5 & 0.510 & 0.3 & Valid \\
\hline 6 & 0.417 & 0.3 & Valid \\
\hline 7 & 0.526 & 0.3 & Valid \\
\hline 8 & 0.398 & 0.3 & Valid \\
\hline 9 & 0.627 & 0.3 & Valid \\
\hline
\end{tabular}

Sumber: Output SPSS 16.0 for Windows, 2012

Tabel 3. Hasil Uji Reliabilitas

\begin{tabular}{ccc}
\hline Variabel & Cronbach Alpha $>\mathbf{0 . 6 0}$ & Keterangan \\
\hline Locus of control $\left(\mathrm{X}_{1}\right)$ & 0,67 & Reliabel \\
Etika Kerja Islam $\left(\mathrm{X}_{2}\right)$ & 0.64 & Reliabel \\
Kinerja Karyawan $(\mathrm{Y})$ & 0.80 & Reliabel \\
\hline
\end{tabular}

Sumber: Output SPSS 16.0 for Windows, 2012

Tabel 4. Uji Multikolinearitas

\begin{tabular}{ccc}
\hline Tolerance & VIF & Keterangan \\
\hline 0.047 & 21.443 & \\
0.064 & 15.620 & Bebas \\
0.026 & 39.037 & \\
\hline
\end{tabular}

Sumber: Output SPSS 16.0 for Windows, 2012
Adapun konsistensi instrumen terhadap variabel yang diukur memiliki nilai Crobanch Alpha $>0,60$ yang berarti instrumen tersebut reliabel. Berdasarkan hasil pengolahan data diperoleh hasil yang dapat dilihat pada Tabel 3 .

\section{Analisis Data}

Konsekuensi penggunaan persamaan regresi klasik adalah pengujian terhadap asumsi-asumsi klasik yang digunakan. Asumsi-asumsi klasik tersebut yang sesuai dengan penelitian ini meliputi asumsi error berdistribusi normal, bebas multikoleniaritas dan tidak terdapat heterokedastisitas.

\section{Uji Normalitas}

Hasil uji One Sample Kolmogorof-Smirnov Test menunjukkan bahwa data terdistribusi secara normal, yaitu nilai Asymp Sig (2-tailed) adalah Y (0.799), $\mathrm{X}_{1}$ (0.957), dan $\mathrm{X}_{2}(0.971)>\alpha(0.05)$.

\section{Uji Multikolinearitas}

Uji multikolerasi hanya dilakukan model regresi moderating, sedangkan model regresi model pertama tidak perlu dilakukan karena hanya terdiri dari variabel bebas. Pada penelitian ini digunakan nilai variance inflation factor (VIF) sebagai indikator ada atau tidaknya multikolinearitas diantara variabel bebas. Hasil uji multikolinearitas yang menunjukkan nilai VIF untuk masing-masing variabel independen dapat dilihat pada Tabel 4.

Nilai VIF yang diperoleh menunjukkan model persamaan satu ada variabel independen yang memiliki nilai VIF lebih dari 10, yang artinya ada korelasi diantara sesama variabel independen. Selain itu, hasil perhitungan nilai tolerance yang kurang dari 0,10 juga menunjukkan adanya multikolinearitas, akan tetapi korelasi ini masih dibawah 95\%, maka dapat dikatakan tidak terjadi multikolonieritas yang serius.

\section{Uji Heterokedastisitas}

Uji Heterokedastisitas hanya dilakukan model regresi 2 sedangkan model regresi model pertama tidak perlu dilakukan karena hanya terdiri dari variabel bebas untuk menguji asumsi ini dilakukan dengan melihat grafik scatterplots antara variabel terikat (ZPRED) dan variabel bebas (SRESID). Berdasarkan grafik scatterplots diperoleh bahwa tidak ada pola yang jelas serta titik-titik (pointpoint) menyebar diatas dan dibawah angka 0 pada sumbu Y, hal ini dapat disimpulkan bahwa tidak terjadi heteroskedastisitas pada model regresi. Grafik scatterplots disajikan pada Gambar 1. 


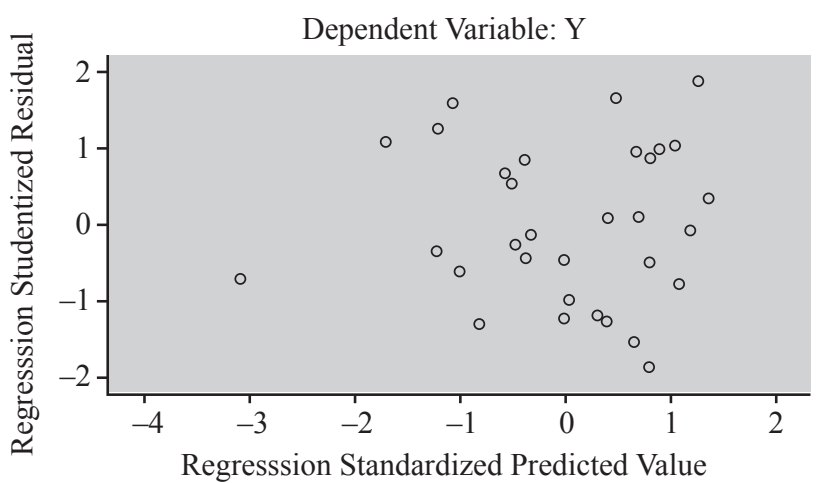

Sumber: Output SPSS 16.0 for Windows, 2012

Gambar 1. Grafik Scatterplots Heterokedastisitas

\section{Regresi Linier Sederhana}

Berdasarkan hasil analisis regresi linier sederhana pada pengujian variabel locus of control terhadap kinerja karyawan diperoleh nilai determinasi, dapat dilihat pada Tabel 5 .

Tabel 5. Hasil analisis uji Koefisien Determinasi (R)

Model Summary ${ }^{\mathrm{b}}$

\begin{tabular}{ccccc}
\hline Model & R & R Square & $\begin{array}{c}\text { Adjusted } \\
\text { R Square }\end{array}$ & $\begin{array}{c}\text { Std. Error } \\
\text { of the Estimate }\end{array}$ \\
\hline 1 & $.546^{\mathrm{a}}$ & .298 & .274 & 4.22172585 \\
\hline
\end{tabular}

a. Predictors: (Constant), Moderat, X2, X1

b. Dependent Variable: $Y$

Sumber: Output SPSS 16.0 for Windows, 2012

Nilai multiple correlation coffecient $(\mathrm{R})$ yaitu $0,546^{\mathrm{a}}$ mendekati nilai angka 1 . Hasil tersebut memperlihatkan bahwa terdapat hubungan yang erat antara variabel bebas locus of control terhadap variabel terikat kinerja karyawan. Korelasi antara variabel bebas dengan variabel terikat bernilai positif dan kekuatan hubungan berada dalam kategori kuat. Selanjutnya, nilai multiple coefficient of determination $\left(\mathrm{R}^{2}\right)$ pada Tabel 5. diperoleh nilai 0.298 yang artinya sebesar $29.8 \%$ kinerja karyawan (Y) dipengaruhi oleh variabel bebas, dan sebesar (100-29.8) $=70,2 \%$ dipengaruhi oleh faktor lain yang tidak termasuk dalam penelitian ini.

Adapun hasil analisis uji signifikansi dilakukan untuk melihat pengaruh variabel bebas terhadap variabel terikat. Berdasarkan hasil pengujian diperoleh nilai $\mathrm{t}_{\text {hitung }} 3.566>\mathrm{t}_{\text {tabel }} 2.042$ dan nilai signifikansi $0.001<\alpha(0.05)$. Hasil tersebut menunjukkan bahwa variabel bebas berpengaruh nyata terhadap variabel terikat atau hipotesis satu $\left(\mathrm{H}_{1}\right)$ diterima. Secara jelas dapat dilihat pada Tabel 6 .
Tabel 6. Koefisien Regresi Uji Signifikasi Persamaan 1 Coefficients $^{\mathrm{a}}$

\begin{tabular}{|c|c|c|c|c|c|c|}
\hline & \multirow{2}{*}{ Model } & \multicolumn{2}{|c|}{$\begin{array}{l}\text { Unstandardized } \\
\text { Coefficients }\end{array}$} & \multirow{2}{*}{$\begin{array}{c}\begin{array}{c}\text { Standardized } \\
\text { Coefficients }\end{array} \\
\text { Beta }\end{array}$} & \multirow{2}{*}{$\mathbf{t}$} & \multirow{2}{*}{ Sig. } \\
\hline & & B & $\begin{array}{l}\text { Std. } \\
\text { Error }\end{array}$ & & & \\
\hline \multirow[t]{2}{*}{1} & (Constant) & 13.180 & 3.477 & & 3.790 & .001 \\
\hline & $\begin{array}{l}\text { Locus Of } \\
\text { control }\end{array}$ & .873 & .245 & .546 & 3.566 & .001 \\
\hline
\end{tabular}

a. Dependent Variable: Kinerja Karyawan

Sumber: Output SPSS 16.0 for Windows, 2012

Berdasarkan hasil perhitungan pada Tabel 6 . dapat dibentuk suatu model persamaan regresi sebagai berikut:

$\mathrm{Y}=13.180+0,873 \mathrm{X}_{1}+\mathrm{e}$

Model ini menggambarkan taksiran atau prediksi terhadap kinerja karyawan yang menjelaskan bahwa locus of control berpengaruh secara positif terhadap kinerja karyawan, yang terlihat dari koefisien regresi yang diperoleh untuk variabel locus of control $\left(\mathrm{X}_{1}\right)$ sebesar 0,873, yang berarti semakin tingginya locus of control yang dimiliki oleh karyawan Bank Mualamat Indonesia Cabang Palu maka semakin tinggi kinerja yang dimiliki.

\section{Moderating Regresi Analysis (MRA)}

Moderating regresi analysis (MRA) digunakan untuk melihat pengaruh etika kerja Islam sebagai variabel moderating di uji dengan (persamaan 2). Model persamaan untuk penelitian ini sebagai berikut:

$\mathrm{Y}=\mathrm{a}+\mathrm{b}_{1} \mathrm{X}_{1}+\mathrm{b}_{2} \mathrm{X}_{2}+\mathrm{b}_{3} \mathrm{X}_{1} \mathrm{X}_{2}+\mathrm{e}$

Berdasarkan hasil olahan data diperoleh nilai multiple correlation coffecient (R) yaitu 0,747 mendekati nilai angka 1. Hasil tersebut memperlihatkan bahwa terdapat hubungan yang erat antara variabel bebas terdapat variabel terikat. Korelasi antara variabel bebas dengan variabel terikat bernilai positif dan kekuatan hubungan berada dalam kategori kuat. Sementara, nilai multiple coefficient of determination $\left(\mathrm{R}^{2}\right)$ adalah 0.558 , yang artinya sebesar $55.8 \%$ kinerja karyawan (Y) dipengaruhi oleh variabel bebas, dan sebesar $(100-55.8)=44.2 \%$ dipengaruhi oleh faktor lain yang tidak termasuk dalam penelitian ini. secara jelas nilai determinasi model persamaan kedua, dapat dilihat pada Tabel 7. 
Tabel 7. Hasil analisis uji Koefisien Determinasi (R)

Model Summary ${ }^{\mathrm{b}}$

\begin{tabular}{lllll}
\hline Model & R & R Square & $\begin{array}{c}\text { Adjusted } \\
\text { R Square }\end{array}$ & $\begin{array}{c}\text { Std. Error of the } \\
\text { Estimate }\end{array}$ \\
\hline 1 & $.747^{\mathrm{a}}$ & .558 & .511 & 3.46505307 \\
\hline
\end{tabular}

a. Predictors: (Constant), Moderat, $\mathrm{X}_{2^{\prime}} \mathrm{X}_{1}$

b. Dependent Variable: $Y$

Sumber: Output SPSS 16.0 for Windows, 2012

Hasil pengujian data untuk koefisien regresi memperlihatkan bahwa syarat pengujian moderating terpenuhi, yaitu hubungan varibel utama berpengaruh secara signifikan. Hasil analisis regresi parsial menggunakan uji $\mathrm{t}$ untuk masing-masing variabel adalah: pengaruh variabel locus of control terhadap kinerja karyawan diperoleh nilai $t_{\text {hit }}(3.433)>t_{\text {tabel }}$ (2.042) dengan nilai signifikan 0,002 $<0,05$. Hasil tersebut maka dapat dijelaskan bahwa variabel locus of control berpengaruh nyata terhadap kinerja karyawan, pengaruh variabel etika kerja Islam terhadap kinerja karyawan diperoleh nilai $t_{\text {hit }}(3.320)$ $>t_{\text {tabel }}(2.042)$ dengan nilai signifikan $0,003<0,05$, dengan hasil tersebut maka dapat dijelaskan variabel etika kerja Islam berpengaruh nyata terhadap kinerja karyawan, dan pengaruh variabel moderating terhadap kinerja karyawan diperoleh nilai $t_{\text {hit }}(-2.615)>t_{\text {tabel }}$ (2.042) dengan nilai signifikan $0,14<0,05$. Hasil tersebut maka dapat dijelaskan variabel moderating berpengaruh nyata terhadap kinerja karyawan atau hipotesis dua $\left(\mathrm{H}_{2}\right)$ terdukung sebagian oleh data yang dianalisis.

Berdasarkan hasil perhitungan pada Tabel 8 . dapat dibentuk suatu model persamaan regresi sebagai berikut:

$Y=-29.549+3.193 X_{1}+2.682 X_{2}-0.144 X_{1} X_{2}+e$

Tabel 8. Koefisien Regresi (Uji t) Persamaan 2

\begin{tabular}{|c|c|c|c|c|c|c|}
\hline & \multirow{2}{*}{ Model } & \multicolumn{2}{|c|}{$\begin{array}{l}\text { Unstandardized } \\
\text { Coefficients }\end{array}$} & \multirow{2}{*}{$\begin{array}{c}\begin{array}{c}\text { Standardized } \\
\text { Coefficients }\end{array} \\
\text { Beta }\end{array}$} & \multirow{2}{*}{$\mathbf{T}$} & \multirow{2}{*}{ Sig. } \\
\hline & & B & $\begin{array}{l}\text { Std. } \\
\text { Error }\end{array}$ & & & \\
\hline \multirow[t]{4}{*}{1} & (Constant) & -29.549 & 13.471 & & -2.193 & .037 \\
\hline & $\begin{array}{l}\text { Locus Of } \\
\text { Control }\left(\mathrm{X}_{1}\right)\end{array}$ & 3.193 & .930 & 1.996 & 3.433 & .002 \\
\hline & $\begin{array}{l}\text { Etika Kerja } \\
\text { Islam }\left(\mathrm{X}_{2}\right)\end{array}$ & 2.682 & .808 & 1.648 & 3.320 & .003 \\
\hline & Moderating & -.144 & .055 & -2.052 & -2.615 & .014 \\
\hline
\end{tabular}

Sumber: Output SPSS 16.0 for Windows, 2012

\section{PEMBAHASAN}

Berdasarkan hasil yang telah didapat maka dapat disimpulkan bahwa penelitian ini mendukung hasil penelitian Noer dan Ikhsan (2007) bahwa locus of control adalah variabel yang berpengaruh lebih dominan terhadap kinerja aparat, dan juga penelitian yang telah dilakukan oleh Julianto (2002), yang menyatakan bahwa locus of control berpengaruh positif terhadap job insecurity.

Irene et al. (2003) menjelaskan bahwa individu yang berorientasi internal menampakkan keyakinan yang lebih besar terhadap kemampuan mereka untuk mempengaruhi lingkungan, lebih mampu dalam menghadapi situasi yang penuh tekanan, lebih banyak mengandalkan cara pemberian pengaruh terbuka dan suportif, menekankan strategi perusahaan yang lebih berisiko dan inovatif serta menghasilkan kinerja yang lebih tinggi daripada yang dilakukan individu yang berorientasi eksternal, sedangkan, didalam dirinya tersimpan potensi besar untuk menentukan nasib sendiri, tidak peduli apakah lingkungannya akan mendukung atau tidak mendukung.

Individu seperti ini memiliki etos kerja yang tinggi, tabah menghadapi segala macam kesulitan baik dalam kehidupannya maupun dalam pekerjaannya. Meskipun ada perasaan khawatir dalam dirinya tetapi perasaan tersebut relatif kecil dibanding dengan semangat serta keberaniannya untuk menentang dirinya sendiri sehingga orang-orang seperti ini tidak pernah ingin melarikan diri dari tiap masalah dalam bekerja.

Berdasarkan hasil regresi secara keseluruhan menunjukkan bahwa locus of control berpengaruh positif dan signifikan terhadap kinerja karyawan. Hasil ini memberikan bukti empiris bahwa semakin tinggi tingkat locus of control yang dinyatakan secara jelas dan spesifik dapat meningkatkan kinerja karyawan Bank Muamalat Indonesia Tbk. Cabang Palu.

\section{Peran Variabel Moderating (Etika Kerja Islam)}

Koefisien interaksi variabel moderating yaitu interaksi antara locus of control dengan etika kerja Islam dengan signifikansi $0,014<0,05$. Hal ini berarti bahwa interaksi antara locus of control dengan etika kerja Islam secara signifikan mempengaruhi kinerja karyawan dengan koefisien regresi $-0,144$, selanjutnya koefisien interkasi $b_{3}$ bertanda negatif memberi arti bahwa variabel etika kerja Islam memperlemah hubungan antara locus of control dengan kinerja 
karyawan di lingkungan karyawan Bank Muamalat Indonesia Tbk. Cabang Palu, peningkatan etika kerja Islam belum dapat memperkuat hubungan antara locus of control dengan kinerja karyawan. Hal tersebut dapat disebabkan oleh faktor atau fenomena yang ada, yaitu masih kurangnya pelatihan tetang etika kerja Islam yang dilakukan di lingkungan Bank Syariah Muamalat, sehingga menyebabkan pemahaman karyawan akan etika kerja Islam masih kurang, perlu juga diperhatikan berdasarkan fenomena yang berkembang di lingkungan perbankan maupun instansi pemerintah yang ada bisa kita lihat masih banyaknya kasus korupsi di Indonesia hal ini bisa disimpulkan walaupaun sudah memiliki etika yang baik berdasarkan ajaran agama akan tetapi godaan atau rayuan untuk memperoleh nilai laba yang besar etika kerja Islam yang dimiliki menjadi mudah terganggu sehingga locus of control atau kontrol diri seseorang lepas sehingga menguragi kinerja yang telah dimiliki.

Berdasarkan hasil yang telah didapat maka dapat disimpulkan bahwa penelitian ini mendukung penelitian sebelumnya, yaitu keterlibatan kerja tidak memediasi hubungan antara etika kerja Islam dengan sikap perubahan organisasi (Anik dan Arifuddin, 2002), dimana tanggapan responden pada pertanyaan terbuka menyatakan bahwa mereka merasakan adanya pengaruh etika kerja Islam terhadap kesesuaian hubungan antara locus of control dan kinerja. Mereka menyatakan bahwa agama merupakan dasar dan pedoman dari kehidupan. Hal ini sesuai dengan sabda Rasulullah Muhammad SAW bahwa bekerja keras menyebabkan terbebas dosa dan tidak seorangpun memakan makanan yang lebih baik kecuali dia makan dari hasil kerjanya, selain itu pandangan etika kerja Islam mendedikasikan diri pada kerja sebagai suatu kebajikan (Fitria, 2003).

Individu yang melihat pemahaman etika kerja Islam seperti diatas didukung pula dengan kepercayaan kuat bahwa nasibnya ditangannya sendiri, maka akan menjadikan seorang individu tersebut menjadi fleksibel dalam menjalani hidup bahkan akan menjadi lebih meningkatkan kinerjanya karena pemahaman agama tadi seakan-akan selalu memberikan dorongan dalam setiap langkahnya, bila dikaitkan dengan hasil penelitian ini hal tersebut belum ditemukan pada karyawan Bank Syariah Muamalat Palu., selanjutnya untuk menguji apakah etika kerja Islam $\left(\mathrm{X}_{2}\right)$ dapat dianggap sebagai variabel moderating, dapat dijelaskan dengan cara membuat persamaan derevasi (turunan) $\mathrm{X}_{1}$ atau $\mathrm{dY} / \mathrm{dX}_{1}$ dari persamaan 2. Hasil $\mathrm{dY} / \mathrm{dX}_{1}$ adalah sebagai berikut:

$\mathrm{Y}$

$$
\begin{array}{ll}
\mathrm{dY} / \mathrm{dX} & =\beta_{1}+\beta_{3} \mathrm{X}_{2} \\
\mathrm{dY} / \mathrm{dX}_{1} & =3.193-0.144 \mathrm{X}_{2} \\
\text { Untuk } \mathrm{X}_{2} & =0, \text { maka } \mathrm{dY} / \mathrm{dX}_{1}=3.193 \\
\text { Untuk } \mathrm{dY} / \mathrm{dX}_{1} & =0, \text { maka }_{2}=22,173
\end{array}
$$

Perhitungan matematis derivasi parsial tersebut juga untuk memperjelas sifat dan arah masing-masing variabel. Hasil perhitungan diatas diketahui titik yang memotong sumbu $\mathrm{Y}\left(\mathrm{dY} / \mathrm{dX}_{1}\right)$ adalah 3.193 dan titik yang memotong sumbu $\mathrm{X}_{2}$ adalah 22,173 yang disebut titik infleksi (inflection point) pada Gambar 2.

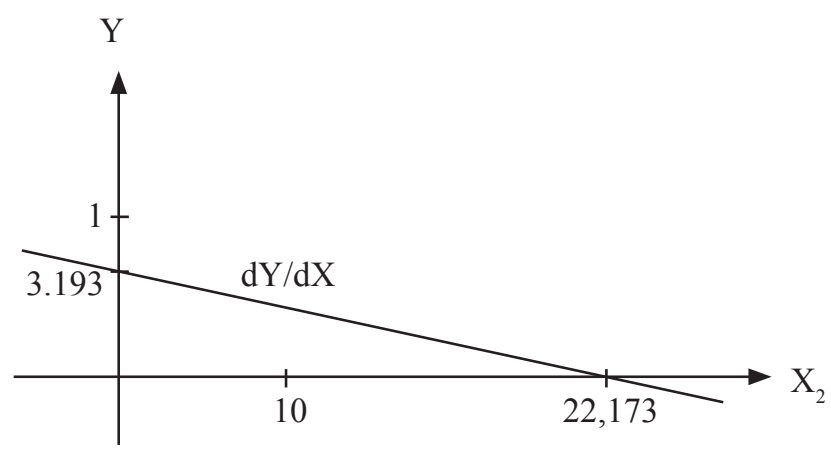

Gambar 2. Grafik Persamaan Derevasi Turunan $\mathrm{X}_{1}$ atau $\mathrm{dY} / \mathrm{dX}_{1}$ dari persamaan 2

Gambar 2. menjelaskan bahwa titik yang memotong sumbu $\mathrm{Y}(\mathrm{dY} / \mathrm{dX1})$ adalah 3.193 dan titik yang memotong sumbu $\mathrm{X} 2$ adalah 22,173 yang selanjutnya disebut titik infleksi. Sumbu vertikal (dY/dX) menunjukan pengaruh locus of control terhadap etika kerja Islam dan sumbu horizontal menunjukan kisaran dari etika kerja Islam, sehingga dapat diartikan bahwa penurunan etika kerja Islam akan menyebabkan penurunan locus of control. Koefisien interaksi $\left(b_{3}\right)$ memiliki nilai negatif sehingga dapat dinyatakan bahwa etika kerja Islam yang rendah memperlemah hubungan antara locus of control dan kinerja karyawan.

\section{KESIMPULAN}

Berdasarkan hasil penelitian yang dilakukan untuk mengetahui pengaruh locus of control terhadap kinerja karyawan dan untuk mengetahui apakah keberadaan variabel moderating; etika kerja Islam 
akan mempengaruhi hubungan antara locus of control terhadap kinerja karyawan, maka dapat ditarik kesimpulan sebagai berikut.

Pengaruh locus of control terhadap kinerja karyawan. Variabel bebas locus of control secara parsial berpengaruh positif dan signifikan terhadap variabel terikat kinerja karyawan.

Pengaruh locus of control terhadap kinerja karyawan dengan etika kerja Islam sebagai variabel moderating. Etika kerja Islam berpengaruh terhadap hubungan antara locus of control dengan kinerja karyawan. di lingkungan karyawan Bank Muamalat Indonesia Tbk. Cabang Palu, peningkatan etika kerja Islam belum dapat memperkuat hubungan antara locus of control dengan kinerja karyawan. Hal ini berarti bahwa dengan adanya etika kerja Islam akan memperlemah kinerja karyawan.

\section{DAFTAR PUSTAKA}

Anik, Sri dan Arifudin. 2003. Analisis Pengaruh Komitmen Organisasi dan Keterlibatan Kerja Terhadap Hubungan Antara Etika Kerja Islam dengan Sikap Perubahan Organisasi. Jurnal Akuntansi dan Auditing Indonesia, 7(2): 159-182.

Ayudiati, Soraya Eka. 2010. Analisis Pengaruh Locus Of Control Terhadap kinerja Karyawan dengan Etika Kerja Islam sebagai Variabel Moderating. Skripsi Tidak Dipublikasikan. Semarang. Universitas Diponegoro.

Dessler, Gary. 2006. Manajemen Sumber Daya Manusia (edisi ke-10). Jakarta: Indeks.

Dewi, Sari Suasana dan Bawono, Icuk Rangga. 2008. Analisis pengaruh Etika Kerja Islam terhadap Sikap Karyawan Bagian Akuntansi dalam Perubahan Organisasi (Studi Kasus pada Bank Umum Non Syariah di Wilayah Eks Karisidenan Banyumas Jawa Tengah). Jurnal Akuntansi dan Auditing Indonesia, 12(1): 65-78.

Engko, Cecilia dan Gudono. 2007. Pengaruh Kompleksitas Tugas dan Locus of Control terhadap Hubungan dan Gaya Kepemimpinan dan Kepuasan Kerja Editor. Jurnal Akuntansi dan Auditing Indonesia, 11(2): 105-124.

Falikhatun. 2003. Pengaruh Budaya Organisasi,Locus Of Control, dan Penerapan Sistem Informasi Terhadap Kinerja Aparat Unit-Unit Pelayanan Publik. Jurnal Empirika, 16(2) Desember: 263-281.
Fitria, Astri. 2003. Pengaruh Etika Kerja Islam terhadap Sikap Akuntan dalam Perubahan Organisasi dengan Komitmen Organisasi sebagai Variabel Intervering. Jurnal Maksi, 3(Agustus): 14-35.

Ghozali, Imam. 2002. Pengaruh Religiositas terhadap Komitmen Organisasi, Keterlibatan Kerja, Kepuasan Kerja, dan Produktivitas. Jurnal Bisnis dan Strategi, 9.

Ida dan Dwinta, Chintia Yohana. 2010. Pengaruh Locus Of Control, Financial Knowledge, Income terhadap Financial Mangement Behavior. Jurnal Bisnis dan Akuntansi, 12(3): 131-144.

Irene, Rini et. al., 2003. Analisis Pengaruh Partisipasi Penyusunan Anggaran terhadap Kinerja Manajerial dengan Kultur Organisasional dan Locus of Control sebagai Moderating (Studi Kasus Pada Pertamina Unit VI Balongan). Jurnal Bisnis Strategi, 11(Juli): 23-33.

Jaya, Eka Danta dan Rahmat, Iksan. 2005. Bornout di Tinjau dari locus Of Control internal dan Eksternal. Jurnal Majalah Kedokteran Nusantara, 38(3): 213-218.

Julianto. 2002. Analisis Pengaruh Kepuasan kerja terhadap locus of control, Konflik Peran, komitmen Organisasi dan Job Insecurity yang Mempengaruhi Keinginan perpindahan Kerja pada Perusahaan Freight Forwarding di Jakarta. Jurnal Empirik, 14(10): 68.

Karimi, Roohangiz dan Alipour, Farhad. 2011. Reduce Job Strees in Organization, Role of Locus Of Control. International Journal of Bussines and Social Science, 2(18): 232-236.

Launita, Maya Febrianty. 2011. Pengaruh Time Budget Pressure, Locus of Control, dan Perilaku Disfungsional Audit Terhadap Kinerja Auditor. Jurnal Telaah dan Riset Akuntansi, 4(1): 92-113.

Mahiyaddin, Rusniyati Binti. 2009. Hubungan Etika Kerja Islam dengan Komitmen Organisasi (Kajian dikalangan KakiTangan Lembaga Urusan Tabung Haji. Tesis. Tidak dipublikasikan. Malaysia: College of Busines, Universitas Utara Malaysia.

Menezes, Alvaro Amaral. 2008. Analisis Dampak Locus of Control terhadap Kinerja dan Kepuasan Kerja Internal Auditor (Penelitian Terhadap Internal Auditor di Jawa Tengah). Tesis. Tidak dipublikasikan. Semarang: Program Pascasarjana, Universitas Diponegoro. 
Mustikawati, Reny. 1999. Pengaruh Locus of Control dan Budaya Paternalistik terhadap Pengefektifan Penganggaran Partisipatip dalam Peningkatan Kinerja Manajerial. Jurnal Bisnis dan Akuntansi, 1(2): 96-119.

Ngatemin. 2009. Pengaruh Komitmen Oraganisasi dan locus of Control Terhadap Hubungan antara Partisipasi Penyusunan Anggaran dan Kinerja Manejerial pada Departemen kebudayaan dan Parawisata RI. Tesis. Tidak Di Publikasikan. Medan: Program Pascasarjana, Universitas Sumatera Utara.

Noer, Mohamad dan Ikhsan Budi Rihardjo. 2007. Pengaruh Budaya Organisasi, Locus Of Control, dan Kebijakan Sektor Publik Terhadap Kinerja Aparat Pelayanan Publik UPT Dipenda Bangkalan. Jurnal Akuntansi, Manajemen Bisnis dan Sektor Publik, 3(2): 219-241.

Prasetyo P., Puji. 2002. Pengaruh Locus of Control Terhadap Hubungan Antara Ketidakpastian Lingkungan dengan Karakteristik Informasi Sistem Akuntansi Manajemen. Jurnal Riset Akuntansi Indonesia, 5(1): 119-136.

Purnomo, Ratno dan Sri Lestari. 2010. Pengaruh Kepribadian, Self-Efficaccy, dan Locus of Control Terhadap Persepsi Kinerja Usaha Skala Kecil dan Menengah. Jurnal Bisnis dan Ekonomi, 17(2): 144-160.
Ribhan. 2008. Hubungan Karakteristik Individu dengan Kinerja Karyawan Melalui Komitmen Organisasi sebagau Variabel Mediasi (Studi Kasus Pada PT Chandra Superstore Tanjung Karang Bandar Lampung). Jurnal Bisnis dan Manajemen, 4(2): 90-110.

Rusdi, Rosnelly dan Septiani, Dian. 2008. Pengaruh Stress Kerja terhadap Kinerja Karyawan pada Redaksi Surat Kabar Harian Umum Lampung Post. Jurnal Bisnis dan Manajemen, 4(2): 201-219.

Sedarmayanti. 2004. Pengembangan Kepribadian Pegawai. Bandung: Mandar Maju.

Sukarno, Gendut. 2003, Analisis Hubungan Antara Stres Kerja Yang Berlocus Of Control Eksternal Dengan Kinerja Karyawan. Jurnal Penelitian Ilmu Ekonomi, 3(1).

Sundary, Rini Irianty. 2010. Internalisasi HukumHukum Islam tentang Etika Kerja dalam Perlindungan Hak Pekerja dan Pelaksanaan Hak atas Pekerjaan. Jurnal Ilmu Hukum (Syiar Hukum), XII(2): 178-188.

Yousef, Danvish A. 2000. Organizational Commitment as a Mediator of the Relationship between Islmaic Work Ethics and Attitudes toward Organizational Change. Jurnal Human Relations, 53(4): 513-517. 